\title{
The making and prevention of rain amongst the Pedi tribe of South Africa: A pastoral response
}

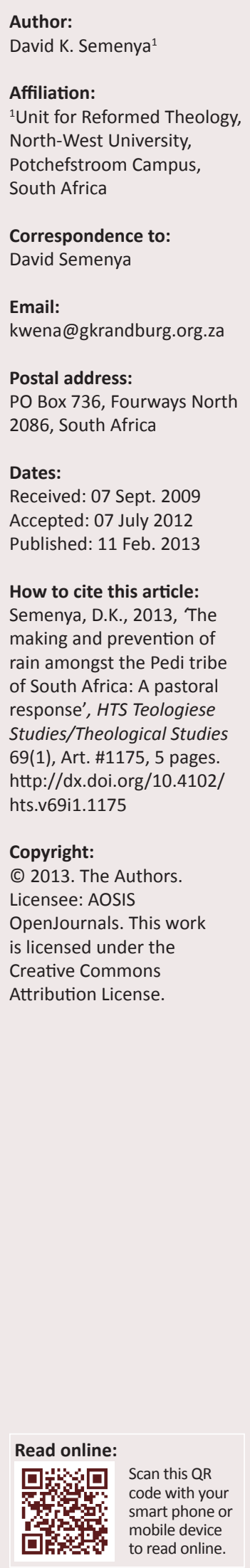

This article attempted to respond pastorally to the rainmaking and rain prevention rituals which are practised among the Pedi tribes - also called the Northern-Sotho speaking nation of South Africa. The rituals of rainmaking and rain prevention have been practised among the Pedi for a long time - these rituals are in fact still being practised in some of the villages in and around the Limpopo Province. The rituals are practised in time of drought and also during activities such as weddings or traditional gatherings, this is normally called molato. When the village is experiencing drought, community members, upon instruction from the chief of the village, stage a rain ritual and the moroka [rain making traditional doctor] would take the lead in performing such rituals. Families would also perform rain prevention rituals when a gathering or a wedding is being organised to ensure that the rain does not disturb the gathering and everything goes as planned. Thus the purpose of rainfall rituals is to influence the weather conditions in order to cause rain or drought either for good or for destruction. The mentioned rituals and selected scriptural passages were discussed. This article presented the biblical view of rain and conclusion principles were formulated to understand the Bible's perspective on the mentioned rituals. These conclusions were used for the formulation of practical guidelines.

\section{Introduction}

It is amazing to think that an individual could invoke the god of rain and request him to send down rain, the god of rain obeys and rain starts falling. Rainmaking is an ancient science that the pagans utilised to water their farms in times of drought. The methods for making rain differ from place to place and according to the severity of the drought. ${ }^{1}$

\section{According to Boddy-Evans (2010):}

Droughts are common in southern Africa, but when the rain does fall there are excellent opportunities for grazing cattle and developing agriculture. So it is not surprising that one of the most critical threats against the well being of a southern African society [is a lack of rain].

Whilst many of the Sotho-speaking groups of Southern Africa [believe in] a supreme being who is ultimately responsible for the weather, rain rituals are predominantly directed towards the ancestors and specifically to the ancestors of the chief - such rituals helped [to] protect and [legitimise] chiefdoms. The chief's ancestors were supposed to intercede on the people's behalf and drought would occur when they were negligent.

One of the best examples of the tribes that are well known for making rain in Southern Africa is the Ba-Lovedu tribe of the Limpopo Province. Since 1800 there have been six rain queens of the Balovedu. Boddy-Evans (2010) points out that the rain queens of the Ba-Lovedu tribe:
are expected to remain unmarried (although they do take female 'wives') and to bear at least one daughter by a royal relative. At the age of 60 , when their powers are perceived to have waned, they are expected to commit suicide by poison - so achieving divine status - at which point the eldest daughter takes over as Rain Queen.

Although voluntary suicides were expected from these rains queens at the age of 60 , however the third Mudjadji [Rain Queen], (ruled 1894-1959) contravened that by:

refusing to drink poison and thus to give up the throne 'even at the age of $80^{\prime}$ - she ruled for eight more years. (It is believed by some that this action placed a curse on the Mudjadji bloodline.) (Boddy-Evans 2010, [author's own emphasis]

Boddy-Evans (2010) further states:

The Mudjadji is considered to be the living embodiment of the rain goddess and is also known by the title Khifidola-maru-a-Daja (transformer of clouds). She is considered the embodiment of the rain, guarantor of the yearly seasonal cycle, and her very emotions are said to be paralleled by the weather.

1.One of the examples is that some villagers use a cooking stick to invoke rain. Virgin girls and boys would steal a cooking stick from a certain house in the village and shout pula! pula (rain! rain!), while running around the village. 
Furthermore, the rain queen's other royal duties includes to preside over an annual rain ceremony held each November.

In describing the rain queens of Ba-Lovedu, Boddy-Evans (2010) states that they maintain their political power by 'marrying' the daughters of district headmen (such womanto-woman marriages are also known amongst the Venda and Pedi). That was evident in the first half of the 19th century, whereby the first Mudjadji was recognised as a significant 'power' in the region - her fame was even acknowledged by the Zulu leader, Shaka kaSenzangakhona, who consulted her about drought in the Zulu kingdom.

\section{Rain-making rituals}

Rainmaking rituals differ from tribe to tribe and from nation to nation. The Pedi also have their way to invoke the god of rain, but again the rituals differ from village to village. In most cases there are special people who have the inspiration or power to perform the art of rainmaking. In the Pedi tribe there is what is called a moroka [rainmaking traditional doctor] (see Pound 1946:133).

In times of drought the village chief calls upon the advice of his or her khudu-thamaga [the managers of the chief's kraal] or his or her batseta [chief's right-hand men] - frequently close relatives) for a kgothakgothe [general meeting] in which the issue of drought is discussed. In the discussion the moroka is allowed to set his or her price for invoking storm-free rain. Normally each household in the village is required to contribute a certain amount of money towards the moroka. A sheep, goat or cow could also be one of the demands of the moroka, before he or she can make rain (the kind of demand depends on the moroka).

It is believed that a drought in a village might be caused by the conflicts amongst the residents in the village or even within the chieftaincy or the leaders of the different traditional leaders. To ensure good rains, leaders must resolve their conflicts and come together for rituals to worship their ancestral spirits. Sometimes a drought could be caused by the moroka if he or she has not been paid by the village. In that case the villagers have to make things right with the moroka, for him or her to release the rain to fall in the village again (Vufhuizen 1997:31).

In most cases a moroka would argue that the rain would depend on the amount of money paid to him or her. This means that if he or she is paid late or too little then he or she will not be able to choose a cloud that will produce good rain for the village, since other Baroka ${ }^{2}$ [rainmaking traditional doctors] will have already chosen clouds that produce good rains. According to Pedi tradition, a moroka is able to fight storm rain and that again depends on the amount paid to him or her.

Other Baroka use a magical horn to invoke rain and this horn is placed in a place believed to be sacred. Only the family of

2.Plural of Moroka. a moroka has access to that place. Moreover, caves can also be used as shelter for the rain medicine. The Pedi and the Tswana make regular sacrifices of corn and beer to the spirits associated with these caves and shelters. The sacrifices are usually accompanied by prayers for rain and crop fertility. All this adds up to the fact that caves or clefts and rock shelters are considered to be mysterious and sometimes even dangerous places, inhabited by superior powers and apparently only visited when contact is needed with these spirits or deities (Aukema 1989:71).

In areas where there are no caves a moroka places his or her rain medicine at a selected place in the backyard garden and builds reeds around it. The place is only visited by the moroka, his or her family or sometimes the person who will succeed him or her after death. Thus following a Pedi proverb that says: Rutang bana ditaola, le se ke la ya le tšona badimong [Convey the tradition and customs to your young generation], meaning that it is the responsibility of the older generation to teach the next generation about traditions and customs before they die.

The Lubedus also use the magical horn to invoke a rain. In 2008 the Mokotos and the Modjadjis fought over the magical horn, which made the Modjadji family pull out of the rainmaking ceremony and perform their own ritual that failed to produce rain. Cyril Mokoto said there would be no rain for as long as the Modjadjis refused to admit that they were not the rightful heirs to the throne. Mokoto said that the Modjadjis were unable to bring forth rain because they did not use the powerful horn to speak to the ancestors for them to bring rain to the drought-prone province (Matlala 2010).

According to the Pedi tradition some Baroka blow a magical horn facing east. Apart from a magical horn, clay pots and also gourds and grindstones are tools used by rainmakers. The grindstone is for grinding the different medicines that then are stirred into the clay pot filled with rainwater. The exact composition of these medicines varies from group to group and from rainmaker to rainmaker. What is apparently important is that when the medicines are stirred, it has to be done so vigorously that froth appears on top of the water and then the medicine is considered fully prepared and ready for use. Using a clay pot and grindstone for preparing medicines seems to be a widespread phenomenon in the southern part of Africa - it is not only used to prepare medicine for communal rites, but also for more common practices such as when a herbalist prepares medicine for a patient (Aukema 1989:70).

Immediately after the moroka has performed the ritual of rainmaking, then he or she informs the chief of the day and the makgamankatšana [virgin girls and boys] who then perform the last phase of rainmaking. During that time the makgamankatšana, accompanied by elders, strike the ground with sticks and pour water from the gourds on each corner of the village, performing what is called go phoka pula [to invoke rain]. The makgamankatšana then walk the streets towards 
each corner of the village, shouting 'pula' 'pula' 'pula' (rain, rain, rain) several times.

Songs are sung by the makgamankatšana along the streets. One of the songs usually sung is:

\begin{tabular}{|c|c|}
\hline Pula tša borare joooo ( $x 2)$ & [Oh! The rain of our fathers] (x2) \\
\hline Pula tša borare ga e ka nâ $(x 2)$ & $\begin{array}{l}\text { [if the rain of our fathers could rain] } \\
(\mathrm{x} 2)\end{array}$ \\
\hline Ya nâ ka medupi & [If it could rain unstoppably] \\
\hline Rena ra tsoga re gata monola & $\begin{array}{l}\text { [so that we may walk on the nourished } \\
\text { ground] }\end{array}$ \\
\hline
\end{tabular}

In most cases there is evidence that it rained immediately or weeks later after the rituals were performed.

\section{Praying for rain}

There is no doubt that when a drought is severe, religious people also approach a chief for a mass prayer for rain in a village. Although the bahetene [heathens] might seek or advise a chief to get a moroka, the rain prayers in the kgotla [chief's kraal] are automatically inclusive. Most adults are expected to attend such prayers (Landau 1993:19). Moreover, in some areas everyone is expected to attend rain prayers.

Rain prayers usually take place near a river or a stream that normally does not dry up even if a drought is severe. Spiritual songs are sung and religious leaders of different churches each take a turn to preach and pray for rain. This usually occurs during the rainy season and the day for rain prayers differs from place to place. Sunday is the most common day for such prayers, since the call for rain prayers is announced at all the churches in time for all members of the community to attend such an event. Rain will sometimes fall immediately after rain prayers.

\section{Rain prevention rituals}

Rain prevention rituals are also performed by a moroka who will often prevent either a rainstorm or prevent rain from falling altogether if not paid by the villagers or even prevent rain from falling if he or she is not recognised in the village as moroka. It may also happen that if the chosen moroka is not strong enough, other Baroka will attempt to prevent him or her from invoking rain so that the chief may approach them for rainmaking - this is usually done out of jealousy. Rain prevention rituals are also performed by ordinary members of the village, during a wedding ceremony or other activities of the household. Rain prevention rituals also differ from village to village. ${ }^{3}$

In olden times people would use the forehead skin of a cow to prevent rain. The forehead skin of a cow was used to make shoes, since it was believed to be strong enough to prevent thorn pricks and thus that it would last longer. These days the forehead skin of a cow is no longer used, instead a modern shoe is used to prevent rain. An old or middle-aged woman

3.Some of the examples are: some cook a mud in a three-legged black pot to prevent rain. Some would carry the lid of a three-legged pot on their back to prevent rain rain. Some would carry the lid of a three-legged pot on their back to prevent rain. centre of the gate with its legs facing upwards. in the family carries a shoe on her back until the end of a ceremony, to prevent rain. When the ceremony is over, she removes the shoe from her back. Sometimes it will start to rain as soon as the shoe is removed from the woman's back.

\section{What does the word of God say about making and preventing rain?}

It often happens that it will start to rain immediately or a little while after the ritual has been invoked by the moroka, yet it sometimes also does happen that it stops raining when the rain prevention ritual is performed. One could ask the question whether people do indeed have the power to make and prevent rain. The fact is that it could also start to rain immediately after prayers for rain by believers in God. Furthermore, in times of drought Christians usually attribute the drought to God's anger over the sins of people.

These occurrences beg the following questions:

- Who provides the rain?

- Who sends drought to the land?

The rituals of rainmaking and rain prevention are recorded in the Old and the New Testament. We read of many gods associated with rainmaking. These gods were believed to be the ones making it rain, and when there was a drought, it would be suggested that it was because of their anger. We read of gods such as Ashtoreth (see 1 Ki 11:11), a goddess who symbolised reproductive power. Dagon was a Philistine god of rain and harvest and the Philistines believed that Dagon was the one who made it rain to enable a bountiful harvest. Many temples were built for him and worship included human sacrifice (Jdg 16:23; 1 Sm 5:2). Turning to 1 Corinthians 10:14, Paul admonishes the church in Corinth to flee from any form of idolatry, because of the many pagan temples that were established in Corinth. In those times people credited statutes of stones or wood with the provision of good weather, crops and children.

Baal was also worshipped as a god of rain and the harvest by the Canaanites. He was represented by a bull, a symbol of strength and fertility. Comparatively, when Jamieson, Fauseset and Brown (1997) discuss what happened in 1 Kings 17:1-14 they argue that Elijah was used by God to demonstrate to all Israel that Yahweh - not Baal - was still the only true God. Perhaps the reports Elijah heard of Jezebel's increasing endeavours to replace the worship of God with Baal stirred up his godly heart. God gave him a mission. Armed with God's promise, he walked westward to Samaria. Bursting into the palace, he hurled an ultimatum at King Ahab and professed that the LORD is the God of Israel. God is alive and that he, Elijah, was God's servant. Elijah could confidently declare that there would be neither dew nor rain because God had promised to withhold rain from the land if his people turned from him to other gods (1 Ki 17:12; 18:10).

In the same way, Mathews (1998), adds that the drought was a refutation of Ahab's Baalism because Baal was reputed to be the god of rain and vegetation. Moreover this showed that 
the Lord was the true Lord of nature. Uniquely from what has been said, Jamieson, Fausset and Brown (1997) argued that:

God had apparently revealed to Elijah that He would honor that promise in Elijah's day. This would have struck at the heart of Baalism, for Baal worshipers believed that their god was the god of rain! (n.p.)

Pastor Mike Smith (2007), in one of his lessons, said: 'The drought, brought on by the true God, showed that $\mathrm{He}$, not Baal, controls the weather.' This was a remarkable demonstration of God's superiority and of the total inadequacy and falsehood of Baal worship.

As has been noted above that God is the only one who could control the rain, the same happened when Judah was about to be restored by God, Zechariah in Chapter 10:1-5, challenged the people to pray to God for rain as opposed to those who sought blessings from the idols which had brought judgements in the land. Verse 1 says 'Ask ... rain'; this denotes a prayer which the nation had to make in order to receive a promise mentioned in Zechariah 9:17. On the same note, Henry (1996) opines that God was and is displeased with idolatry and would chastise them for it by the want for rain, which, when he withheld it, it was not in the power of the gods they served to bestow; for '... are there any of the vanities of the heathen that can give rain?' - (Jr 14:22), which would effectually prove their impotency and the folly of those who left the living God. This proves that the source of natural blessings (rain and plants of the field) is God, not idolatrous and deceptive false shepherds.

However, although God is the one who makes the rain or the one who could withhold the rain, Walvoord and Zuck (1985) argue that his children should be responsible and ask for rain through prayers, since only the Lord alone can give it and will give it when asked (cf. Zch 10:13; 14:22). To add to what has been said by Walvoord and Zuck above, Keil and Delitzsch (2002) assert that children of God are also called to take responsibility by asking for rain, even though God is the one who makes it rain. It is interesting to note that in Deuteronomy 28:1-14 it is shown how God opens the heavens for the rain to pour on to the land of his people when the people live according to his Word and are obedient to him.

To emphasise that Walvoord and Zuck (1985) add, that when God sees that his people obey him, he will send rain and the crops will be plentiful. Isaiah 30:23-26 uses the Hebrew word natan which in this case means 'to give'. Therefore, this shows that when the nation obeys God, then God will give them the blessings of rain, whereby every creature will have plenty to eat and God's people will enjoy abundance of water in the land.

In short, one can conclude that rain is one of the blessings that God gives to his people. In the final analysis, SpenceJones (2004) argued that rain is one of the signs that show that God has forgiven his people; God renews the blessings of his providence, giving his people rain from heaven for fruitful seasons, filling their hearts with food and gladness. The same goes for the Book of Joel 2:23-32, that when God restores his nation he gives rain to his people whereby his people have to rejoice.

Pfeiffer (1962) says that in as much as the nation will be rejoicing, the nation should remember that God's mercy made that possible. Important to realise is that Joel 2:23-32 repeatedly mentions that God gave the nation 'the former rain ... the rain ... the former ... the latter rain.' According to Jamieson et al. (1997) the repetition of the word 'rain' implies that God will give rain not merely for the exigency of that particular season when the prophet Joel spoke, but also for the future in the regular course of nature.

Referring to Psalm 147:8-9, Jamieson et al. (1997) say that people should in return praise God musically and that God should be praised for his greatness in creation (Ps 147:4-5). He sustains plant and animal life with rain and food. God should furthermore be praised because even though he is so great, he delights not in the mighty, but in anyone who trusts him. This is more evidence of his grace (cf. Ps 147:3, 6; 12-14, 19-20).

\section{Biblical principles as deduced from above}

In summary, the most compelling evidence from the passages discussed above is that rain is a gift from God. God can make rain according to his own will, or withhold rain due to people's sin. The gods and man are not responsible for rainmaking or rain prevention.

However, the first thing to remember is that it is the responsibility of God's people to pray to God for rain. As has been noted, God gives rain to sustain his people and other creatures of his creation and people should, therefore, thank and praise God for providing rain.

\section{Conclusion}

The Bible's point of view is that rain is a gift from God. The Bible depicts a God who can make or withhold rain, the gods are not responsible for rainmaking or rain prevention. The fact that it rains or stops raining after the performance of rainmaking and rain prevention rituals, does not mean that people or the moroka or even gods have the power over the rain. If God does not want it to rain, it will never rain and if he wants it to rain it will rain according to his own will (cf. Jer 14:22; Zch 10:1-5). Now the essential issue that still needs to be properly addressed is how then would one explain the issue that it sometimes happens that it will start raining immediately or a little while after rain has been invoked by a moroka or it sometimes also does happen that it stops raining when the rain prevention ritual was performed.

Although the above may seem to be the truth to those practicing the rituals of rainmaking and rain prevention, 
the writer's argument is that, there is nowhere in the Bible where the rain rituals are supported as the truth. Therefore, one can argue that these rituals, as described in this article, have some sort of superstition attached to them, because they cannot be proven by reason or even by the word of God that they are real.

On the other hand, the same argument can be used by those who believe in the rain rituals, that it cannot be proven by reason that God can stop or make it rain. As was shown above the reason can therefore be given from the selected passages from the Bible that God has been and is the one who still provides or prevents the rain according to his will. God, after creating everything, did not leave things to run on their own. Equally important is that God gives rain to sustain his people and other creatures of his creation. He continuously sustains and maintains them according to his will (Mt 10:30 \& 31; cf. Ursinus \& Olevianus 1979). To say that man or the gods can invoke or prevent rain is to limit the providence and the power of the Holy God. However, it is the responsibility of God's people to pray to God for rain. Moreover, Christians should, therefore, thank and praise God for providing rain.

\section{Practical guidelines}

The church should always pray for rain, not only in times of drought. Sermons on the gift of rain should be preached to congregants to teach them that rain is from God, not from the gods. Another key point is that the church should also guide its members - through the Word of God - to keep them from becoming involved in so-called rainmaking rituals as no man can make or prevent rain. This will make members in the church realise that rain is from God not from Baroka. Otherwise, if the aforesaid guideline is not adhered to, this will lead to a form of syncretism within the church of God.

Equally important is that the church should also teach against members who engage a rain specialist to invoke rain, despite the fact that this is a way of honouring ancestors and making the rain specialist a mediator between them and the ancestors. On the same note, the writer wants to emphasise that the church as the body of Christ, should behave differently compared to the world thus aligning their actions with God's word. It would be unwise of the members of the church to engage themselves in any form of rain rituals especially when these are not supported by any scriptural passage in the Bible.
For the purpose that these guidelines be followed by the members of the church, the writer therefore suggests that a service group that concentrates on a special day for prayers should be formed or, if such a group has already been established, special prayer and thanksgiving for rain should be included in their calendars. On a positive note, this will in a way monitor and encourage members to fully participate in the activities of the church.

With the above in mind, the service group, together with the church council, should then organise teachings or miniconferences with the intention to teach the congregation about the providence of God, in which the blessing of rain from God would be part of that discussion.

\section{Acknowledgements Competing interests}

The author declares that he has no financial or personal relationship(s) which may have inappropriately influenced him in writing this article.

\section{References}

Aukema, J., 1989, 'Rain-Making: A Thousand Year-Old Ritual?', The South African Archaeological Bulletin 44(150), 70-72, viewed 06 April 2011, from http://www. jstor.org/stable

Boddy-Evans, A., 2010, 'Rain rituals in Southern Africa and a royal succession lasting centuries', in Rain Queens of Africa, viewed 05 September 2011, from http:// rainqueensofafrica.com/2011/03/the-lovedu-rain-queen/

Henry, M., 1996, Matthew Henry's commentary on the whole Bible, Hendrickson, Peabody, MA.

Jamieson, R., Fausset, A.R. \& Brown, D. 1997, A commentary, critical and explanatory, on the Old and New Testaments, Logos Research Systems Inc., Oak Harbor, WA.

Keil, C.F. \& Delitzsch, F., 2002, Commentary on the Old Testament: (1Ki 17:1-18), Hendrickson, Peabody, MA.

Landau, P.S., 1993, 'When Rain Falls: Rainmaking and Community in a Tswana Village', The International Journal of African Historical Studies 26(1), 1-30, viewed 06 April 2011, from http://www.jstor.org/stable

Mathews, K.A., 1998, 'The historical books', in D.S. Dockery (ed.), Holman concise Bible commentary: Simple, straightforward commentary on every book of the Bible, pp. 1-278, Broadman \& Holman Publisher, Nashville, TN.

Matlala, A., 2010, 'Fight over horn that brings rain', Sowetan, 11 October, p. 14.

Pfeiffer, C.F., 1962, The Wycliffe Bible Commentary: Old Testament (Joel 2:23), Moody Press, Chicago, IL.

Pound, L., 1946, 'Nebraska Rain Lore and Rain Making', California Folklore Quarterly 5(2), 129-142, viewed 06 April 2011, from http://www.jstor.org/stable

Smith, M., 2007, '1st Kings Series: Lesson \#68 (06/03/07) // 1st Kings Chapter 17', in Country Bible Church, viewed 25 September 2011, from http://www. countrybiblechurch.us

Spence-Jones, H.D.M., 2004, The pulpit commentary: Exodus, vol. 1, CD-ROM, Logos Research Systems, Inc., Bellingham, WA.

Ursinus, Z. \& Olevianus, C., 1979, 'Heidelberg Catechism. Thus we believe, thus we confess', Belgic Confession Art 13, The Doctrinal Standards of the Dutch Reformed Church, Andrew Murray Ward, Windhoek. PMid:543336

Vufhuizen, C., 1997, 'Rain-Making, Political Conflicts and Gender Images: A Case from Mutema Chieftaincy in Zimbabwe', Zambezia XXXIV(i), 31-49.

Walvoord, J.F. \& Zuck, R.B., 1985, The Bible knowledge commentary: An exposition of the Scriptures, Victor Books, Wheaton, IL. (Dallas Theological Seminary). 